\title{
A unique late Eocene coleoid cephalopod Mississaepia from Mississippi, USA: New data on cuttlebone structure, and their phylogenetic implications
}

Larisa A. Doguzhaeva, Patricia G. Weaver, and Charles N. Ciampaglio

Acta Palaeontologica Polonica 59 (1), 2014: 147-162 doi: http://dx.doi.org/10.4202/app.2011.0208

A new family, Mississaepiidae, from the Sepia-Spirula branch of decabrachian coleoids (Cephalopoda), is erected on the basis of the following, recently revealed, morphological, ultrastructural and chemical traits of the cuttlebone in the late Eocene Mississaepia, formerly referred to Belosaepiidae: (i) septa are semi-transparent, largely chitinous (as opposed to all other recorded cephalopods having non-transparent aragonitic septa); (ii) septa have a thin lamello-fibrillar nacreous covering (Sepia lacks nacre altogether, Spirula has fully lamello-fibrillar nacreous septa, ectochochleate cephalopods have columnar nacre in septa); (iii) a siphonal tube is present in early ontogeny (similar to siphonal tube development of the Danian Ceratisepia, and as opposed to complete lack of siphonal tube in Sepia and siphonal tube development through its entire ontogeny in Spirula); (iv) the lamello-fibrillar nacreous ultrastructure of septal necks (similar to septal necks in Spirula); (v) a sub-hemispherical protoconch (as opposed to the spherical protoconchs of the Danian Ceratisepia and Recent Spirula ); (vi) conotheca has ventro-lateral extension in early ontogenetic stages (as opposed to Sepia that has no ventro-lateral extention of the conotheca and to Spirula that retains fully-developed phragmocone throughout its entire ontogeny). Chitinous composition of septa in Mississaepia is deduced from (i) their visual similarity to the chitinous semi-transparent flange of Sepia, (ii) angular and rounded outlines and straight compressive failures of the partial septa and mural parts of septa similar to mechanically-damaged dry rigid chitinous flange of Sepia or a gladius of squid, and (iii) organics consistent with $\square$-chitin preserved in the shell. The family Mississaepiidae may represent a unknown lineage of the Sepia-Spirula branch of coleoids, a conotheca lacking a nacreous layer being a common trait of the shell of this branch. However, Mississaepiidae is placed with reservation in Sepiida because of similarities between their gross shell morphology (a cuttlebone type of shell) and inorganic-organic composition. In Mississaepia, as in Sepia, the shell contains up to $6 \%$ of nitrogen by weight; phosphatised sheets within the dorsal shield may have been originally organic, like similar structures in Sepia; accumulations of pyrite in peripheral zones of aragonitic spherulites and in-between the spherulites of the dorsal shield may also indicate additional locations of organics in the shell of living animal. 
Key words: Cephalopoda, Coleoidea, cuttlebone, lamello-fibrillar nacre, chitin septa, fossilization, Eocene, Mississippi, USA.

Larisa A. Doguzhaeva [larisa.doguzhaeva@nrm.se], Department of Palaeozoology, Swedish Museum of Natural History, P. O. Box 50007, SE-104

05 Stockholm, Sweden; Patricia G. Weaver [trish.weaver@gmail.com],

North Carolina Museum of Natural Sciences, 11 West Jones Street,

Raleigh, NC 27601-1029, USA; Charles N. Ciampaglio [chuck.ciampaglio@wright.edu], Department of

Geology, Wright State University-Lake Campus, 7600 State Route 703, Celina, OH 45822, USA.

This is an open-access article distributed under the terms of the Creative Commons

Attribution License (for details please see creativecommons.org), which permits unrestricted use, distribution, and reproduction in any medium, provided the original author and source are credited.

FaF Full text $(1,825.3 \mathrm{kB})$ 